\title{
Methods of physical treatment for a post-polio adult with scoliosis
}

\author{
B Torres
}

From 8th International Conference on Conservative Management of Spinal Deformities and SOSORT 2011 Annual Meeting

Barcelona, Spain. 19-21 May 2011

\section{Objectives}

To describe favorable results in functional postural to enhance and maximize lumbar lordosis at L1/L2 level as well as thoracic kyphosis, increasing the possibility of correcting the postural part of scoliosis in 3D and adding ergonomics.

\section{Case report}

A 69 years old female with $85^{\circ}$ left thoracic scoliosis and bone fusion surgery at 19 years old at T10/T12 level with onset of pain and disability following menopause. The patient had chronic pains as measured on the Roland and Morris VRS as 4 (very strong).

\section{Methods}

The ScoliologiC "Best Practice" program with physi-logic exercises, correction of ADL (activities of daily living), 3Dmade easy with " maximum " possible corrections for the past two years and Lehnert-Schroth exercises, starting seven years ago.

\section{Results}

The patient is able to maximize corrections, free of pain during standing, walking, exercising for $1 / 2$ hour, sitting and resting on bed using proper ergonomics. Roland and Morris VRS value actually in 0-1 (no pain/ little pain).

\section{Conclusions}

With thoughtful and reasonable organized physical activities, the patient is able to control her physiological and scoliotic curves, preventing pain, improving the cosmetics, vitality, endurance, functional activities and well being.

Private Practice, Palo Alto, USA
Published: 27 January 2012

\section{References}

1. Lehnert-Schroth C: Three-dimensional treatment for scoliosis. The Martindale Press; 2007.

2. Weiss HR: The method of Katharina Schroth - history, principles and current development. Scoliosis 2011, 6:16.

doi:10.1186/1748-7161-7-S1-P25

Cite this article as: Torres: Methods of physical treatment for a postpolio adult with scoliosis. Scoliosis 2012 7(Suppl 1):P25.
Submit your next manuscript to BioMed Central and take full advantage of:

- Convenient online submission

- Thorough peer review

- No space constraints or color figure charges

- Immediate publication on acceptance

- Inclusion in PubMed, CAS, Scopus and Google Scholar

- Research which is freely available for redistribution
C Biomed Central

\section{() Biomed Central}

